\title{
First report of Cymbidium mosaic virus and Odontoglossum ring spot virus in Argentina
}

\author{
Silvina Edith Cánovas ${ }^{1} \cdot$ María Celeste Ballari $^{1} \cdot$ Claudia Fernanda Nome $^{2}$
}

Received: 26 October 2015 / Accepted: 10 December 2015 / Published online: 14 December 2015

(C) Australasian Plant Pathology Society Inc. 2015

\begin{abstract}
Oncidium Sharry Baby orchids from nursery greenhouses in Buenos Aires, Argentina with viral symptoms were processed for transmission electron microscope observations. Two types of viral particles, morphologically different, were observed. The aim of this work is identification of viral particles infecting the orchids. Serological analysis and partial genome sequence confirmed the presence of Cymbidium mosaic virus (CymMV) and Odontoglossum ring spot virus (ORSV). To our knowledge this is the first report of ORSV and CymMV in Argentina.
\end{abstract}

Keywords Cymbidium mosaic virus · Odontoglossum ring spot virus · Oncidium Sharry Baby $\cdot$ Partial genome sequence . Transmission electron microscopy $\cdot$ Cytological alterations

Orchids are ornamental plants within the Orchidaceae family, which are commonly affected by numerous pathogens. Cymbidium mosaic virus, CymMV, a potexvirus and Odontoglossum ringspot virus, ORSV, a tobamovirus are known worldwide for their dispersion, economic impact and prevalence (Labrín et al. 2005). These viruses are usually spread during plant replanting and flower harvesting, with contaminated tools. Previous researches have confirmed mixed infections of CymMV and ORSV in different orchid

Claudia Fernanda Nome

cfnome@yahoo.com.ar

1 Facultad de Ciencias Exáctas, Fisicas y Naturales, Univesidad Nacional de Córdoba, Av. Velez Sarfield 299, 5000 Córdoba, Argentina

2 Instituto de Patología Vegetal, Instituto Nacional de Tecnología Agropecuaria, Camino 60 Cuadras, km 5,5,

5019 Córdoba, Argentina genera (Inouye and Gara 1996; Wisler 1989). Intracellular alterations occurring in the mixed infection have not been described yet. Among ornamental orchids commercialized in the world there are numerous hybrids, such as the genus Oncidium $s p$ which is one of the most appreciated plants for its fragrance, for example the Oncidium Sharry Baby 'Sweet Fragrance' ( $O$. Jaime Sutton X O. Honolulu) (Yee et al. 2008).

During 2010, in a greenhouse in the province of Buenos Aires, Oncidium Sharry Baby plants with symptoms of leaf chlorosis and necrotic sports were observed (Fig. 1a and b). These were transferred to the Institute of Plant Pathology (IPAVE) at the City of Córdoba, Argentina, for further studies. The aim of this work was to identify the causative agents, and describe the intracellular alterations induced.

Symptomatic Oncidium Sharry Baby leaf tissue was analyzed by transmission electron microscopy, Dip preparations were made with borate buffer $0,05 \mathrm{M} \mathrm{pH} 7$ and stained with $2 \%$ uranile acetate (Kitajima and Nome 1999). The observations showed viral particles, rigid rods approximately 330 $334 \mathrm{~nm}$ long, 18-22 nm wide (Fig. 2a) and filamentous flexible particles $460-500 \mathrm{~nm}$ long and $13-14 \mathrm{~nm}$ wide (Fig. 2b). These observations suggested the presence of a potexvirus and a tobamovirus (Labrín et al. 2005).

Total RNA extractions were performed using ZR Plant RNA MiniPrep ${ }^{\mathrm{TM}}$ (Zymo Research) following suppliers instructions. RT-PCR was performed with generic primers for potexviruses and tobamoviruses. One-tube RT-PCR was made for the potexviruses reaction with MuMLV reverse transcriptase (Epibio), Hotstart Taq polymerase (Promega) and a pair of primers for CymMV designed in this work (Potex-CN-R 5CGgCATAAGTCATGCAACGG-3 and Potex-CN-F 5GCCTCTCTCGCCTATGTCAC-3). The reaction was an initial incubation for $1,30 \mathrm{~h}$ at $37^{\circ} \mathrm{C}$, denaturation for $10 \mathrm{~min}$ at $94{ }^{\circ} \mathrm{C}, 35$ cycles with denaturation for $30 \mathrm{~s}$ at $94^{\circ} \mathrm{C}$, annealing for $45 \mathrm{~s}$ at $57{ }^{\circ} \mathrm{C}$, extension for $1 \mathrm{~min}$ at $72{ }^{\circ} \mathrm{C}$ and final 
Fig 1 a: O. Sharry Baby from the province of Buenos Aires. Leaves showing symptomatology of chlorotic and necrotic spots, $\mathbf{b}$ : chlorotic mosaic symptoms. Symptoms observed on host plants with CymMV and ORSV coinfection; c: Chenopodium quinoa with chlorotic spots 4 days after ORSV inoculation

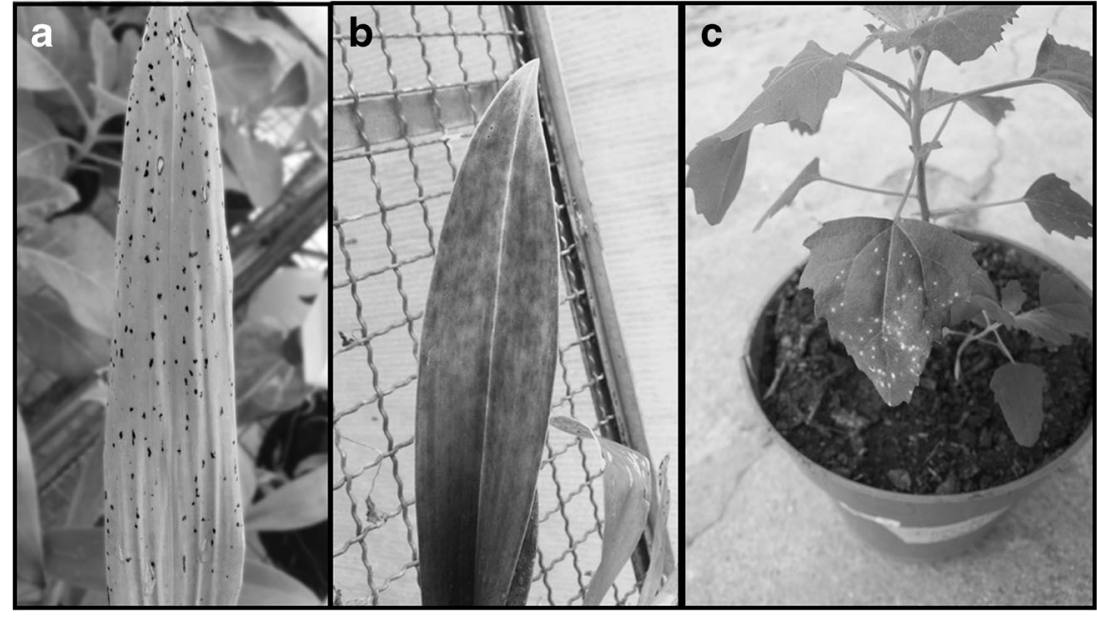

extension at $72{ }^{\circ} \mathrm{C}$. The Tobamovirus reaction was performed in two steps using the Tob-Uni 1 and 2 primers (Letschert et al. 2002), retrotranscription with MuMLV enzime (Promega) incubated for $1,30 \mathrm{~h}$ at $37^{\circ} \mathrm{C}$, followed of PCR using $4 \mu \mathrm{l}$ of the $\mathrm{RT}$ reaction, denaturation for $10 \mathrm{~min}$ at $94^{\circ} \mathrm{C}, 35$ cycles with denaturation for $30 \mathrm{~s}$ at $94^{\circ} \mathrm{C}$, annealing for $45 \mathrm{~s}$ at $60{ }^{\circ} \mathrm{C}$, extension for $1 \mathrm{~min}$ at $72{ }^{\circ} \mathrm{C}$, and final extension at $72{ }^{\circ} \mathrm{C}$. Agarose gel electrophoresis of amplified products with tobamovirus and CymMV primers showed the expected band size (680-700 bp for tobamovirus and $650 \mathrm{bp}$ for CymMV). The PCR products were purified, cloned and sequenced. Sequence analysis was performed with the NCBI nucleotide blast tool. Blast results for tobamovirus product revealed partial sequences of ORSV movement protein (MP) and Coat protein (CP), and for CymMV the partial fragment of the RNA-dependent RNA-polymerase (RdRp). Sequences were deposited in GenBank with accession numbers KT733673 and KT733672 respectively. Serological test for Cymbidium mosaic virus (CymMV) and Odontoglossum ring spot virus
(ORSV) was carried out with Adgia immunostrips according to supplier instructions, for the Oncidium Sharry Baby symptomatic leaves. The strips showed positive reaction for both CymMV and ORSV. Asymptomatic Oncidium Sharry Baby was used as negative control.

To obtain the viral isolates, consecutive mechanical inoculations from a single local spot symptom were performed, in Chenopodium quinoa and Chenopodium amaranticolor for ORSV isolation (Fig. 1c), and in Datura stramonium for CymMV isolation. After 3 successive inoculations from a single spot, the isolates were accomplished, checked by RT-PCR and electron microscopy. Samples of the isolates and the coinfection were included in Spurr low viscosity resin.

The description of cellular organelles alterations with the mixed infection and each isolate was performed in a Jeol 1220 EXII transmission electron microscope.

The ORSV and CymMV coinfetion was studied on Oncidium Sharry Baby, Ch. amaranticolor, D. stramonium and Gomphrena globosa leaf tissues. The observations in all
Fig 2 Dip preparation of chlorotic and necrotic spots of Oncidium Sharry Baby observed under electron microscope showing a: rigid filamentous ORSV- type particles, and b: flexuous filamentous CymMV-type particles. Bar $=100 \mathrm{~nm}$

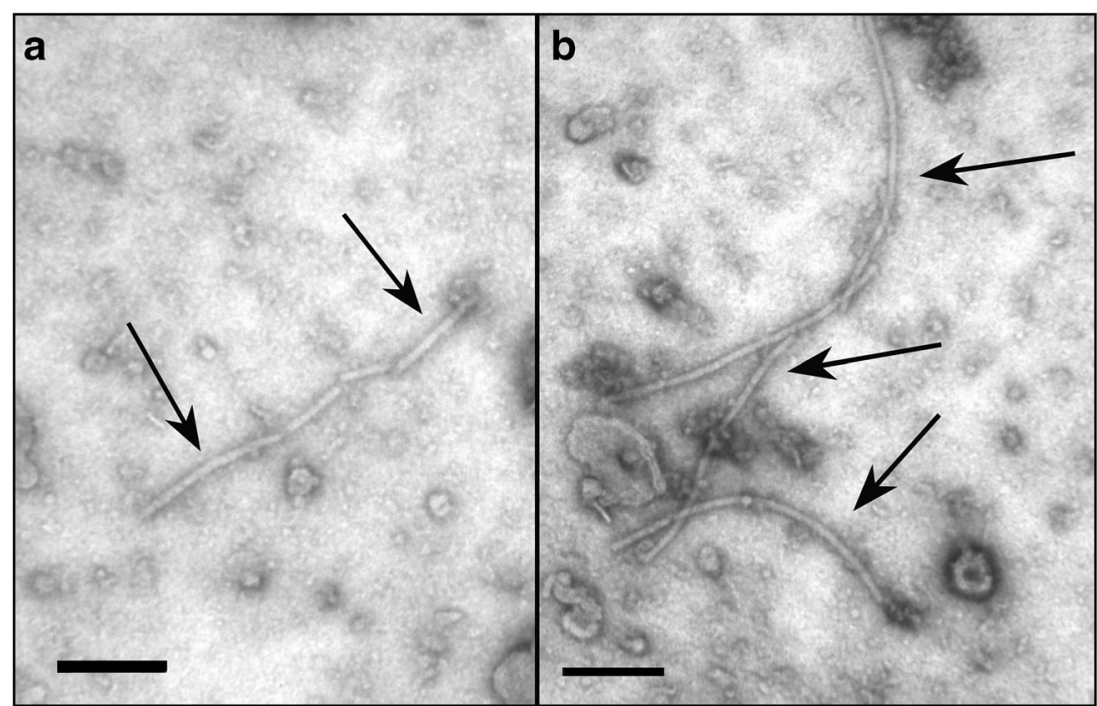


the cases showed most of the mitochondrias with empty spaces inside, vesicles proliferation in the cytoplasm, and accumulation of lipid-like globules inside chloroplasts. Viral particles were always found spread in the cytoplasm and central vacuole of mesophyll and parenchyma cells, not so for the epidermis, vascular tissues, nor inside other organelles. In G. globosa particles were also found inside vesicles in the cytoplasm.

ORSV isolate was studied in Ch. amaranticollor and Ch. quinoa. The observations showed mitochondrias with empty spaces inside, chloroplasts with accumulation of lipid-like globules, and enlarged plastoglobules inside the chloroplasts. Viral particles were found aggregated in the cytoplasm, inside cytoplasmic vesicles and central vacuoles of mesophyll and parenchyma cells.

Observations made in D. stramonium infected with CymMV isolate showed mitochondrias with empty spaces inside, and vesicles proliferation. Viral particles were organized in palisade bundles and spiral shapes (in cytoplasm of mesophyll cells.

Based on the results of mechanical inoculations of the virus isolates, we can affirm that $C$. quinoa and $C$. amaranticolor are better hosts for ORSV and D. stramonium for CymMV, even though they are not selective hosts in neither case.

The study of cytological alterations made in this report shows that the Argentinean ORSV, isolated or in mixed infection with CymMV, induces the accumulation of large lipidlike globules. These lipid-like globules have been cited for other viruses of the same genus (Inouye 1973) and other genera (Medina et al. 2003), but had never been observed for ORSV isolation.

CymMV isolate in D. stramonium, did not show viral particles in the nucleus, chloroplasts or mitochondria, neither forming crystals, inclusions nor spread, unlike other potexviruses. Observations showed spread particles, palisade and spiral arrangements inside the cytoplasm, occupying most of the infected cell, same as scattered inside the central vacuole and vesicles in the cytoplasm containing particlelike filaments (Francki et al. 1985; Milicic and Stefanac 1971; Labrín et al. 2005).

To our knowledge this is the first report of ORSV and CymMV in Argentina.

\section{References}

Francki RIB, Milne G, Hatta T (1985) Tobamovirus and potexvirus groups. In: Francki R I B, Milne G, Hatta T (Eds) Atlas of plant viruses. CRC Press, Boca Raton. p. 103-127 and p. 147-169

Inouye T (1973) Host range and electron microscopy of burdock mottle virus, a rod-shaped virus from Arctium lappa L.: studies on the viruses of plants in compositae in Japan. Okayama Univ Ber Ohara Inst Landw Biol 15:207-218

Inouye N, Gara W (1996) Detection and identification of virases of orchids in Indonesia. Bull Res Inst Bioresour Ocayama Univ 4:109-118

Kitajima EW, Nome CF (1999) Técnicas de microscopia electrónica. In: Docampo DM, Lenardón SL (Eds) Métodos para detectar patógenos sistémicos Pugliese Siena, Córdoba, Argentina. p. 59-87

Labrín N, Rancel E, Schmidt A, Centeno F, Campos A (2005) Virus del mosaico del Cymbidium y de la mancha anillada del Odontogossum identificado en un híbrido de cattleya proveniente del municipio Revenga, estado Aragua, Venezuela. Rev Mex Fitopatol 23:57-61

Letschert B, Adam G, Lesemann D, Willingmann P, Heinze C (2002) Detection and differentiation of serologically cross-reacting tobamoviruses of economical importance by RT-PCR and RT-PCRRFLP. J Virol Meth 106 1/10 www.elsevier.com/locate/jviromet

Medina V, Rodrigo G, Tian T, Juarez M, Dolja V, Achon MA, Falk B (2003) Comparative cytopathology of Crinivirus infections in different plant hosts. Assoc Appl Biol 143:99-110

Milicic D, Stefanac Z (1971) Cell in inclusions of the Cucumber green mottle virus and the Odontoglossum rings pot virus. Acta Bot Croat 30:33-40

Wisler GC (1989) How to control orchid viruses. The complete guidebook. Maupin House Publishers, Gainesville, p 31

Yee NC, Abdullah OJ, Mahmood M, Basiron N (2008) Co-transfer of $g f p$, CHS and hptII genes into Oncidium Sharry Baby PLB using the biolistic gun. Afr J Biotechnol 7(15):2605-2617 